\title{
Enzymes of B-Ring-Deoxy Flavonoid Biosynthesis in Elicited Cell Cultures of "Old Man" Cactus (Cephalocereus senilis) ${ }^{1}$
}

\author{
Qin Liu, ${ }^{*}$ Maureen S. Bonness, ${ }^{*}$ Ming Liu, ${ }^{*}$ Espanta Seradge,* \\ Richard A. Dixon, $\dagger^{+2}$ and Tom J. Mabry* \\ *Department of Botany, The University of Texas at Austin, Austin, Texas 78713; and †Plant Biology Division, \\ The Samuel Roberts Noble Foundation, P.O. Box 2180, Ardmore, Oklahoma 73402
}

Elicited cell cultures of the cactus Cephalocereus senilis produce a group of flavonoids with unsubstituted B-rings, including an aurone which represents a new class of phytoalexin. Preliminary enzymological studies indicated that the chalcone synthase (CHS) and chalcone isomerase (CHI) from cultures of $C$. senilis were active with cinnamoyl-CoA and $2^{\prime}, 4^{\prime}, 6^{\prime}$-trihydroxychalcone, respectively, probable intermediates for synthesis of flavonoids with unsubstituted B-rings. We now demonstrate that the cultures contain two isoforms of CHI, both of which are induced by elicitor treatment and are active with both $2^{\prime}, 4,4^{\prime}, 6^{\prime}$-tetrahydroxy- and $2^{\prime}, 4^{\prime}, 6^{\prime}$-trihydroxychalcone. (Hydroxy)-cinnamate:CoA ligase in the cactus cultures was active with cinnamic, 4-coumaric, caffeic, ferulic, and 4methoxycinnamic acids, but not sinapic acid. A single form of CoA ligase, as resolved by chromatofocusing analysis, was active against both cinnamate and 4coumarate. Cinnamic acid 4-hydroxylase (CA4H) activity was induced by elicitor treatment. Thus, elicited cultures contain the necessary enzymatic activities for synthesis of B-ring-hydroxy and -deoxy flavonoids. Synthesis of only the deoxy class in response to elicitation may result from some form of metabolic compartmentation through which the CA4H reaction is bypassed, leading to formation of cinnamoyl CoA which may then be incorporated into B-ring deoxy flavonoids via nondiscriminating CHS and CHI activities. 1995 Academic Press, Inc.

Key Words: flavonoid biosynthesis; enzyme induc-

\footnotetext{
${ }^{1}$ This work was supported at the University of Texas at Austin by the Samuel Roberts Noble Foundation, the National Institutes of Health (GM-35710), and the Robert A. Welch Foundation (F-130).

${ }^{2}$ To whom correspondence should be addressed at Plant Biology Division, The Samuel Roberts Noble Foundation, P.O. Box 2180, Ardmore, OK 73402. Fax: (405) 221-7380.
}

tion; cinnamic acid 4-hydroxylase; (hydroxy)-cinnamate:CoA ligase; chalcone isomerase; elicitation.

Phytoalexins have long been proposed to be important factors in resistance to plant pathogens, and it has recently been demonstrated that transgenic plants producing a novel phytoalexin have enhanced disease resistance (1). The isoflavonoid phytoalexins of leguminous crop plants such as alfalfa, soybean, and bean have been extensively studied, at both enzymological and molecular genetic levels (2-5). We have developed Cephalocereus senilis ("old man" cactus) as a model system for phytoalexin research on drought-adapted plants (6). Cell cultures of this cactus have an interesting response to microbial infection and elicitor treatment, producing a series of unusual flavonoid derivatives. Chemical analysis of cultures elicited with chitin led to the discovery of a group of flavonoids lacking a hydroxyl group at the $4^{\prime}$ position of the B-ring (Fig. 1) $(7-10)$. One of these flavonoids was characterized as a new aurone, cephalocerone, representing a new class of phytoalexins. For comparison, we examined the flavonoids produced in stem tissues of old man cactus plants and found that these possess the usual 4'-hydroxyl group (11). The lack of flavonoids in unelicited cultures and the appearance of the B-ring unsubstituted compounds following elicitation indicate that a novel biosynthetic pathway is induced by elicitors.

The biosynthetic origin of flavonoids with unsubstituted B-rings is not fully understood. 4-Coumaric acid was thought to be the exclusive precursor for plant flavonoids, except for a few cases where caffeic acid was utilized (12). However, Paré et al. (6) demonstrated that both 4-coumaroyl-CoA and cinnamoyl-CoA were 


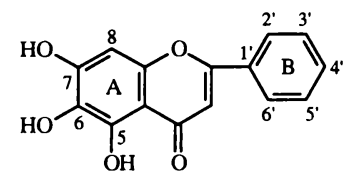

Baicalein

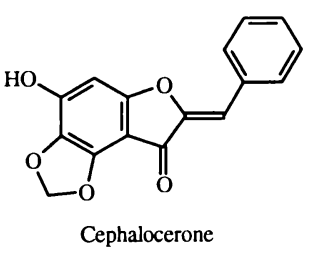

Cephalocerone
FIG. 1. Examples of B-ring unsubstituted flavonoids isolated from elicited cultures of $C$. senilis.

substrates for the chalcone synthase (CHS) ${ }^{3}$ in elicited old man cactus cultures and that both $2^{\prime}, 4,4^{\prime}, 6^{\prime}$-tetrahydroxychalcone and $2^{\prime}, 4^{\prime}, 6^{\prime}$-trihydroxychalcone were substrates for the subsequent enzyme, chalcone isomerase (CHI) (Fig. 2). However, it was not clear whether this dual substrate specificity reflected the presence of single CHS and CHI forms that were active on both classes of substrate or the presence of isoforms that could discriminate between the different B-ring substitution patterns. CHS activity with cinnamoylCoA was recently reported to be present in Scots pine (Pinus sylvestris) (13).

In this paper we show that elicited cultures of $C$. senilis contain all the enzymatic activities necessary for the formation of both B-ring hydroxy and B-ring deoxy flavonoids, according to the pathways shown in Fig. 2. Specifically, the cultures contain two forms of $\mathrm{CHI}$, but both are capable of converting chalcone with or without the B-ring 4-hydroxyl group into flavonoids. The enzyme (hydroxy)-cinnamate:CoA ligase (generally referred to as 4-coumarate:CoA ligase, 4CL) usually shows a strong preference for hydroxy- or methoxysubstituted cinnamic acids; the cactus enzyme is able to efficiently activate unsubstituted cinnamic acid to its CoA thiol ester. We propose that flux into the Bring-unsubstituted flavonoid pathway in elicited cells occurs as a result of the presence of this unusual (hydroxy)-cinnamate CoA ligase activity along with some novel form of metabolic compartmentation which bypasses the cinnamic acid 4-hydroxylase $(\mathrm{CA} 4 \mathrm{H})$ reaction, thus leading to the formation of cinnamoyl CoA, the key substrate for the formation of B-ring deoxy flavonoids.

\section{MATERIALS AND METHODS}

Plant material. Cell suspension cultures derived from stem tissue of $C$. senilis were grown as described previously $(6,7)$. Cells were elicited by addition of autoclaved chitin to a final concentration of $0.25 \mathrm{mg}$ chitin per ml culture (9).

\footnotetext{
${ }^{3}$ Abbreviations used: PAL, phenylalanine ammonia-lyase; $\mathrm{CA} 4 \mathrm{H}$, cinnamic acid 4-hydroxylase; 4CL, 4-coumarate:CoA ligase; CHS, chalcone synthase; $\mathrm{CHI}$, chalcone isomerase; NMR, nuclear magnetic resonance; PVPP, polyvinylpolypyrrolidone; Bis-Tris, bis(2-hydroxyethyl)iminotris(hydroxymethyl)methane.
}

Young plants (3-4 years old) of $C$. senilis and other cacti were purchased from Living Desert Nursery (Austin, TX). Petunia hybrida was obtained from a local plant nursery. Cut parsley was purchased from a local grocery store. A voucher of $C$. senilis is deposited in the Plant Resources Center, The University of Texas at Austin.

Preparation of chalcones. $2^{\prime}, 4,4^{\prime}, 6^{\prime}$-Tetrahydroxychalcone and $2^{\prime}, 4^{\prime}, 6^{\prime}$-trihydroxychalcone were prepared from the flavanones naringenin (Sigma, St. Louis, MO) and pinocembrin (Indofine Chemical Company, Belle Mead, NJ), respectively, according to Moustafa and Wong (14), except that the alkali treatment of pinocembrin was carried out at $70^{\circ} \mathrm{C}$ instead of $100^{\circ} \mathrm{C}$. The chalcones were purified over a silica gel column eluted with $\mathrm{CH}_{2} \mathrm{Cl}_{2}-\mathrm{MeOH}$ containing increasing amounts of $\mathrm{MeOH}$. The structures of the chalcones were confirmed by ${ }^{1} \mathrm{H}-\mathrm{NMR}$ and uv spectroscopy. The molar extinction coefficient of $2^{\prime}, 4,4^{\prime}, 6^{\prime}$-tetrahydroxychalcone at $400 \mathrm{~nm}, \mathrm{pH} 8$, was 33,113 (15) and that of $2^{\prime}, 4^{\prime}, 6^{\prime}$-trihydroxychalcone in $60 \mathrm{mM} \mathrm{KH}_{2} \mathrm{PO}_{4}, \mathrm{pH} 8$, containing $50 \mathrm{~mm} \mathrm{KCN} \mathrm{(the} \mathrm{assay} \mathrm{buffer} \mathrm{for} \mathrm{CHI}$ ), was determined to be 16,982 .

Extraction and separation of CHI isoforms by chromatofocusing. All of the following procedures for enzyme extraction and purification were carried out at $4^{\circ} \mathrm{C}$ unless otherwise noted.

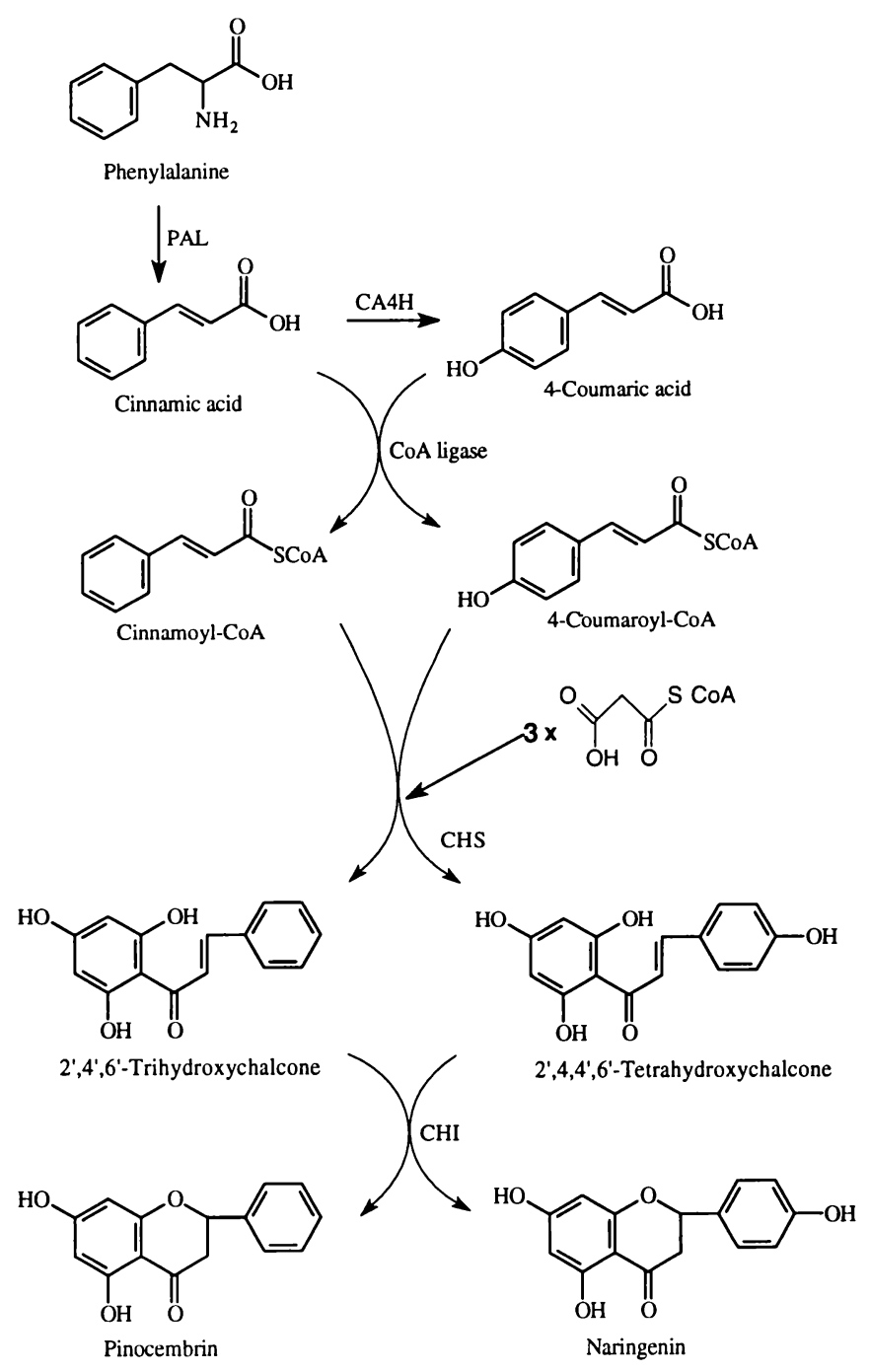

FIG. 2. Biosynthetic pathways leading to B-ring unsubstituted and substituted flavonoids in $C$. senilis. 
CHI was extracted by homogenizing frozen cactus culture cells $(20 \mathrm{~g})$ in $40 \mathrm{ml}$ of $50 \mathrm{~mm}$ Tris $-\mathrm{HCl}, \mathrm{pH} 8.5$, containing $1.4 \mathrm{~mm} \mathrm{2-}$ mercaptoethanol in the presence of $5 \%(\mathrm{w} / \mathrm{v})$ polyvinylpolypyrrolidone (PVPP). The homogenate was squeezed through four layers of cheesecloth, centrifuged at $25,000 \mathrm{~g}$ for $20 \mathrm{~min}$, and the supernatant subjected to ammonium sulfate fractionation. The pellet which precipitated between 40 and $80 \%$ saturation was dissolved in $5 \mathrm{ml}$ of homogenization buffer and desalted through two PD-10 columns (Pharmacia, Uppsala, Sweden). A sample containing $10.58 \mathrm{mg}$ protein was applied to a chromatofocusing column $(1 \times 20 \mathrm{~cm})$ packed with polybuffer exchanger 94 (Pharmacia) which had been equilibrated with $150 \mathrm{ml}$ of $25 \mathrm{~mm}$ Bis-Tris/HCl, $\mathrm{pH} 6.3$, containing $2 \mathrm{~mm}$ dithiothreitol. The column was eluted with $7 \%$ polybuffer $74, \mathrm{pH} 4$, containing $2 \mathrm{mM}$ dithiothreitol. Ninety fractions $(2 \mathrm{ml}$ each) were collected. For examining $\mathrm{CHI}$ in $\mathrm{H}_{2} \mathrm{O}$-treated (control) cactus cultures, $10.46 \mathrm{mg}$ of protein material was loaded onto the column and the collection volume was $3 \mathrm{ml}$.

CHI was extracted from chlorenchyma tissue of 3- to 4-year-old $C$. senilis plants by peeling off the epidermis and excising the thin underlying dark green layer of tissue. This layer was chosen as it contained markedly less mucilage than stem cross-sections. A sample from the chlorenchyma tissue containing $10.60 \mathrm{mg}$ protein was analyzed by chromatofocusing as above, but collecting $5.5-\mathrm{ml}$ fractions. The fractions with $\mathrm{CHI}$ activity were combined and subjected to a second round of chromatofocusing, with $1-\mathrm{ml}$ fractions being collected.

CHI assay. CHI activity was determined according to Edwards and Kessmann (15). The kinetics of the reaction were monitored by measuring the decrease in absorbance at $400 \mathrm{~nm}$ for $2^{\prime}, 4,4^{\prime}, 6^{\prime}$ tetrahydroxychalcone and at $366 \mathrm{~nm}$ for $2^{\prime}, 4^{\prime}, 6^{\prime}$-trihydroxychalcone. The control decrease of absorbance in the absence of enzyme extracts was subtracted.

Extraction and partial purification of (hydroxy)cinnamate:CoA ligase by chromatofocusing. Cactus culture cells $(150 \mathrm{~g})$ harvested $24 \mathrm{~h}$ after elicitation were homogenized in a mortar in $300 \mathrm{ml}$ of 0.1 $\mathrm{M}$ Tris/ $\mathrm{HCl}, \mathrm{pH} 7.8,14 \mathrm{~mm}$ 2-mercaptoethanol, and $30 \%$ (v/v) glycerol in the presence of $5 \%(\mathrm{w} / \mathrm{v})$ PVPP. After centrifugation at $25,000 \mathrm{~g}$ for $20 \mathrm{~min}$, the supernatant was treated with $5 \%$ (w/v) Dowex-1 ion exchange resin which had been preequilibrated with the same buffer and then subjected to ammonium sulfate fractionation. Proteins which precipitated between 40 and $80 \%$ saturation were collected and desalted on PD-10 columns in the buffer $(25 \mathrm{~mm}$ Bis-Tris $/ \mathrm{HCl}$, $\mathrm{pH} 6.5,2 \mathrm{mM}$ dithiothreitol, $30 \%$ glycerol) in which the chomatofocusing column had been equilibrated. A sample containing $52.95 \mathrm{mg}$ of protein was loaded onto the column which was eluted as for $\mathrm{CHI}$ except that the buffer contained 30\% glycerol. Fraction size was $1.25 \mathrm{ml}$.

(Hydroxy) cinnamate:CoA ligase assay. The activity of CoA ligase was determined using a direct spectrophotometric assay (16). Formation of CoA esters was monitored at the relevant wavelengths, and the amount of product formed was calculated using previously reported extinction coefficients. In controls, $\mathrm{CoASH}$ was replaced with Tris buffer.

Preparation of microsomal fractions. Microsomal fractions were prepared from cultured cactus cells (5-10 g cells per time point) essentially as described by Edwards and Kessmann (15). Cells were homogenized in extraction buffer $\left(0.1 \mathrm{M} \mathrm{KH}_{2} \mathrm{PO}_{4}, \mathrm{pH} 7.5,0.4 \mathrm{M}\right.$ sucrose, $28 \mathrm{~mm} 2$-mercaptoethanol) $(1 \mathrm{~g}$ cells/ml buffer $)$ in a mortar in the presence of Dowex-1 (200-400 mesh preequilibrated in the same buffer) and acid-washed sand. Homogenates were centrifuged at $8000 \mathrm{~g}$ for $15 \mathrm{~min}$, filtered through Miracloth, and the supernatants centrifuged at $135,000 \mathrm{~g}$ for $80 \mathrm{~min}$. Pellets were washed with $1 \mathrm{ml}$ resuspension buffer $\left(0.1 \mathrm{M} \mathrm{KH}_{2} \mathrm{PO}_{4}, \mathrm{pH} 7.5,0.4 \mathrm{M}\right.$ sucrose, $3.5 \mathrm{mM}$ 2-mercaptethanol) and resuspended in 350- $\mu$ l resuspension buffer for CA4H assays. Microsomes were assayed for the marker enzyme $\mathrm{NADH}$-dependent cytochtome $\mathrm{C}$ reductase by the method of Wray and Filner (17).

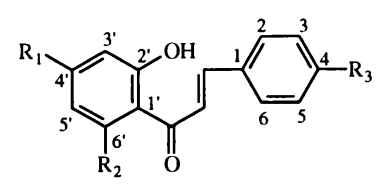

$\begin{array}{lccc}\text { Chalcones } & \mathbf{R}_{1} & \mathbf{R}_{2} & \mathbf{R}_{3} \\ & & & \\ 2^{\prime}, 4,4^{\prime}, 6^{\prime} \text {-tetrahydroxy } & \mathrm{OH} & \mathrm{OH} & \mathrm{OH} \\ 2^{\prime}, 4^{\prime}, 6^{\prime} \text {-trihydroxy } & \mathrm{OH} & \mathrm{OH} & \mathrm{H} \\ 2^{-} \text {-hydroxy } & \mathrm{H} & \mathrm{H} & \mathrm{H} \\ 2^{\prime} \text {-hydroxy-4-methoxy } & \mathrm{H} & \mathrm{H} & \mathrm{OMe} \\ 2^{\prime}, 4^{\prime} \text {-dihydroxy-4-methoxy } & \mathrm{OH} & \mathrm{H} & \mathrm{OMe} \\ 2^{\prime}, 4,4^{\prime} \text {-trihydroxy } & \mathrm{OH} & \mathrm{H} & \mathrm{OH}\end{array}$

FIG. 3. Structures of the chalcones tested on C. senilis CHI.

CA4H assay. The activity of $\mathrm{CA} 4 \mathrm{H}$ was determined by a modification of the HPLC method described by Edwards and Kessmann (15). Fifty microliters of microsomal preparation was preincubated with $480 \mu \mathrm{l} 0.1 \mathrm{M} \mathrm{KH}_{2} \mathrm{PO}_{4}, \mathrm{pH} 7$, and $20 \mu \mathrm{l}$ cinnamic acid $(2 \mathrm{mM}$ in $\mathrm{CH}_{3} \mathrm{CN}$ ) for $5 \mathrm{~min}$ at $30^{\circ} \mathrm{C}$. The reaction was initiated by adding 50 $\mu \mathrm{l}$ of $20 \mathrm{~mm}$ NADPH and incubating for $60 \mathrm{~min}$ at $30^{\circ} \mathrm{C}$. The reaction was stopped by adding $40 \mu \mathrm{l} 6 \mathrm{~N} \mathrm{HCl}$ and the resulting solution was partitioned twice with $0.6 \mathrm{ml}$ EtOAc (water-saturated), removing $0.45 \mathrm{ml}$ of the organic phase after each extraction. The EtOAc extract was evaporated under vacuum. The residue was redissolved in 100 $\mu \mathrm{l} \mathrm{CH}_{3} \mathrm{CN}: \mathrm{H}_{2} \mathrm{O}(1: 1)$ and the resulting solution analyzed by HPLC using an Altex Ultrasphere-octyl column or Econosphere column (250 $\times 4.6 \mathrm{~mm}, 5 \mu \mathrm{m})$. The mobile phase was a mixture of $\mathrm{CH}_{3} \mathrm{CN}$ and $1 \%$ aqueous $\mathrm{H}_{3} \mathrm{PO}_{4}(40: 60)$ with a flow rate of 0.8 or $1.0 \mathrm{ml} / \mathrm{min}$. Peaks were monitored with a HP1040M diode array detector. UV spectra of peaks were compared to the spectrum of authentic 4-coumaric acid. A calibration curve for 4-coumaric acid (0-40 nmol) was established. Controls consisted of incubations in which the reaction was stopped at zero time or carried out in the absence of either NADPH or cinnamic acid.

Protein determination. Protein concentrations were determined by the BioRad dye-binding assay according to the manufacturer's method, using bovine serum albumin as a standard.

\section{RESULTS}

\section{Substrate Specificity and Induction of Cactus CHI}

The substrate specificity of the CHI activity in crude extracts from chitin-elicited cell cultures was examined with six chalcones: $2^{\prime}, 4,4^{\prime}, 6^{\prime}$-tetrahydroxychalcone, $2^{\prime}, 4^{\prime}, 6^{\prime}$-trihydroxychalcone, $2^{\prime}$-hydroxychalcone, $2^{\prime}$-hydroxy-4-methoxychalcone, $2^{\prime}, 4^{\prime}$-dihydroxy-4-methoxychalcone, and $2^{\prime}, 4,4^{\prime}$-trihydroxychalcone (Fig. 3). Only $2^{\prime}, 4,4^{\prime}, 6^{\prime}$-tetrahydroxychalcone and $2^{\prime}, 4^{\prime}, 6^{\prime}$-trihydroxychalcone were found to be substrates for the enzyme.

The utilization of $2^{\prime}, 4^{\prime}, 6^{\prime}$-trihydroxychalcone by CHI has not, to the best of our knowledge, been previously reported in any other system (6). In order to determine whether cactus CHIs are unique in their substrate specificity, we examined the substrate specificity of $\mathrm{CHI}$ in crude extracts from five cactus species as well as petunia and parsley. $\mathrm{CHI}$ from the two latter species is known to catalyze the isomerization of $2^{\prime}, 4,4^{\prime}, 6^{\prime}$-tetrahydroxychalcone (18). All the cell extracts examined 
TABLE I

Activity of CHI in Crude Extracts from Various Sources with $2^{\prime}, 4,4^{\prime}, 6^{\prime}$-Tetrahydroxychalcone or $2^{\prime}, 4^{\prime}, 6^{\prime}$-Trihydroxychalcone as Substrates

\begin{tabular}{|c|c|c|}
\hline \multirow[b]{2}{*}{ Enzyme source } & \multicolumn{2}{|c|}{ Specific activity ( $\mu$ kat/g protein) } \\
\hline & $2^{\prime}, 4,4^{\prime}, 6^{\prime}$-Tetrahydroxychalcone & $2^{\prime}, 4^{\prime}, 6^{\prime}$-Trihydroxychalcone \\
\hline \multicolumn{3}{|l|}{ Cactus species } \\
\hline Cephalocereus senilis stem & 2.86 & 4.52 \\
\hline C. senilis culture (NE) & 9.34 & 28.58 \\
\hline C. senilis culture $(\mathrm{E})$ & 18.2 & 46.69 \\
\hline Echinocactus horizonthalonius stem & 0.41 & 0.76 \\
\hline E. horizonthalonius culture (NE) & 1.52 & 6.08 \\
\hline E. horizonthalonius culture (E) & 3.13 & 9.22 \\
\hline Stenocereus thurberi stem & Not detected & Not detected \\
\hline Opuntia spp. stem & 0.53 & 0.95 \\
\hline Myrtillocactus geometrizans stem & 0.62 & 1.81 \\
\hline \multicolumn{3}{|l|}{ Noncactus species } \\
\hline Parsley_-whole plant & 1.26 & 2.99 \\
\hline Petunia-flower & 2.74 & 6.48 \\
\hline
\end{tabular}

Note. E, elicited; NE, nonelicited.

were more active against the 4-deoxy chalcone than the tetrahydroxychalcone (Table I). It is not known whether the other cactus species accumulate B-ring deoxy flavonoids.

The question of whether the isomerase activity with $2^{\prime}, 4,4^{\prime}, 6^{\prime}$-tetrahydroxychalcone and $2^{\prime}, 4^{\prime}, 6^{\prime}$-trihydroxychalcone is due to dual substrate specificity of a single enzyme or to two distinct enzymes was addressed by chromatofocusing analysis (Fig. 4A). Although two isoforms of $\mathrm{CHI}$ with $\mathrm{pIs}$ of 5.0 and 4.8 were revealed by chromatofocusing, activities against the two substrates were not separable. Both forms of CHI from C. senilis exhibited dual specificity.

To determine if either of the two isoforms is specifically induced by elicitation, the pattern of $\mathrm{CHI}$ isoforms from $\mathrm{H}_{2} \mathrm{O}$-treated (control) cultures was also analyzed (Fig. 4B). Nonelicited cultures also contained two isoforms of CHI. Comparison of Figs. 4A and 4B indicates that both forms of $\mathrm{CHI}$ are induced by chitin treatment.

The activities of the two isoforms of $\mathrm{CHI}$ as a function of various substrate concentrations were determined for $2^{\prime}, 4,4^{\prime}, 6^{\prime}$-tetrahydroxychalcone and $2^{\prime}, 4^{\prime}, 6^{\prime}$-trihydroxychalcone. The two peaks of CHI activity, partially purified by chromatofocusing, were used for the assays. The $K_{m}$ values for $2^{\prime}, 4,4^{\prime}, 6^{\prime}$-tetrahydroxychalcone as determined by Lineweaver-Burk double reciprocal plots were $16.2 \mu \mathrm{M}$ for isoform I and $11.9 \mu \mathrm{M}$ for isoform II. For $2^{\prime}, 4^{\prime}, 6^{\prime}$-trihydroxychalcone, the $K_{m}$ was $4.0 \mu \mathrm{M}$ for isoform I and 7.2 $\mu \mathrm{M}$ for isoform II.

Chemical investigation of flavonoids from intact plants of old man cactus has established that these contain a B-ring $4^{\prime}$-hydroxyl group and are thus typical of the type found in most plants (11). The activity of $\mathrm{CHI}$ from cactus stems was examined. This CHI was also able to use both $2^{\prime}, 4,4^{\prime}, 6^{\prime}$-tetrahydroxychalcone and $2^{\prime}, 4^{\prime}, 6^{\prime}$-trihydroxychalcone as substrates. As in cactus cell cultures, the activities of cactus stem $\mathrm{CHI}$ against $2^{\prime}, 4,4^{\prime}, 6^{\prime}$-tetrahydroxychalcone and $2^{\prime}, 4^{\prime}, 6^{\prime}$ trihydroxychalcone were not separable by chromatofocusing (Fig. 5A). However, only one form of CHI was found in cactus stems. To improve the resolution of the chromatofocusing analysis, fractions containing CHI activity were combined and subjected to a second round of chromatofocusing with smaller fraction volumes being collected. Again only one peak of $\mathrm{CHI}$ activity was resolved (Fig. 5B).

\section{Substrate Specificity and Induction of C. senilis (Hydroxy) Cinnamate:CoA Ligase}

The substrate specificity of CoA ligase in crude extracts from both elicited and unelicited cactus cells was determined using various cinnamic acid derivatives as substrates. With the exception of sinapic acid, all (hydroxy) cinnamic acids tested were substrates for the CoA ligase activity (Table II). Highest activity was seen for caffeic acid, but cinnamic acid was also a good substrate (73\% of the activity observed for caffeic acid). The relative activities against cinnamic and 4-coumaric acids were almost identical.

The induction time courses of CoA ligase activity with both 4-coumaric and cinnamic acids as substrates were determined for chitin-elicited and unelicited cactus cultures (Fig. 6). Activities against both substrates showed similar increases within $12 \mathrm{~h}$ after elicitation and reached a maximum after $24 \mathrm{~h}$. Unelicited cultures showed no increase in CoA ligase activity against either substrate. 

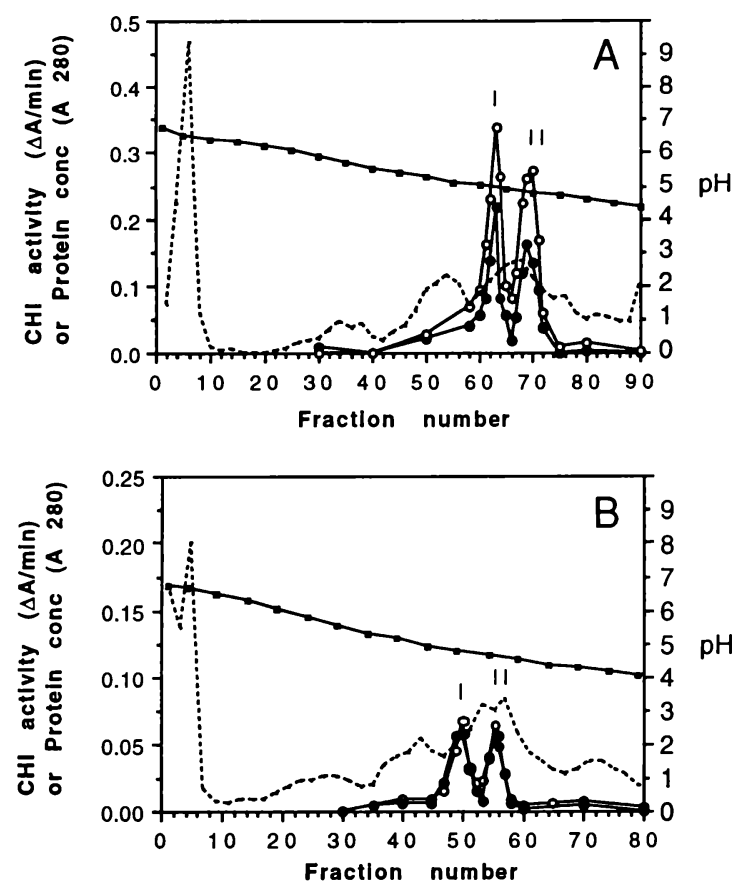

FIG. 4. Separation of two CHI isoforms (I and II) by chromatofocusing of extracts from chitin-elicited (A) and nonelicited (B) cell cultures of $C$. senilis. Enzyme activities were measured with $2^{\prime}, 4,4^{\prime}, 6^{\prime}$-tetrahydroxychalcone $(\bullet)$ or $2^{\prime}, 4^{\prime}, 6^{\prime}$-trihydroxychalcone $(O)$ as substrates. Activity represents the activity of $25 \mu \mathrm{l}$ of each fraction. The columns were eluted with polybuffer to give a $\mathrm{pH}$ gradient (ם) from 7 to 4 . Fraction size was $2 \mathrm{ml}$ in $\mathrm{A}, 3 \mathrm{ml}$ in B. Protein concentration (-.-.-) was determined by measuring $A_{280}$.

Cinnamic acid is not commonly an effective substrate for (hydroxy) cinnamate:CoA ligase. It was therefore important to determine whether there were two or more CoA ligases in the elicited cactus cultures or one enzyme with multiple substrate specificity. Chomatofocusing revealed only a single form of (hydroxy) cinnamate:CoA ligase in the cactus cells (Fig. 7), with apparent $\mathrm{p} I$ of 4.6. This was active against both cinnamic and 4-coumaric acids.

\section{Elicitation of $\mathrm{CA} 4 \mathrm{H}$ Activity}

Having established that the elicited cactus cultures contain both cinnamate and coumarate $\mathrm{CoA}$ ligase activities, the simplest explanation for the origin of Bring deoxy flavonoids in the elicited cactus cultures would be a lack of induction of $\mathrm{CA} 4 \mathrm{H}$ activity, leading to formation of cinnamate with no conversion to 4coumarate. $\mathrm{CA} 4 \mathrm{H}$ activity was therefore determined in microsomal preparations of both nonelicited and elicited cactus cultures. As support for the above explanation would be critically dependent on our not underestimating the $\mathrm{CA} 4 \mathrm{H}$ activity, we tested many parameters to optimize the assay of the enzyme in cactus micro- somes, based on the procedure of Edwards and Kessmann (15), and repeated the experiment on several independent batches of elicited cactus cultures. We found that it was essential to use freshly harvested rather than frozen cells, although microsomal preparations could themselves be frozen without significant loss of activity. The cactus $\mathrm{CA} 4 \mathrm{H}$ was more active at $\mathrm{pH} 7.5$ than at $\mathrm{pH} 8.0$, and dithiothreitol could not be substituted for 2-mercaptoethanol. NADH-dependent cytochrome $\mathrm{C}$ reductase activity was measured as a microsomal marker enzyme.

A typical time course for changes in the activities of $\mathrm{CA} 4 \mathrm{H}, \mathrm{NADH}$-dependent cytochrome $\mathrm{C}$ reductase and PAL is shown in Fig. 8. CA4H activity was clearly induced, from an undetectable basal level. The induction kinetics were broadly similar to those of PAL (Fig. 8) and the cinnamate CoA ligase (Fig. 6), with a major increase in activity between 8 and $16 \mathrm{~h}$ postelicitation.

\section{DISCUSSION}

Chemical analysis of chitin-elicited cactus cultures has led to the identification of a series of induced flavonoids with unsubstituted B-rings $(8-10)$, whereas,

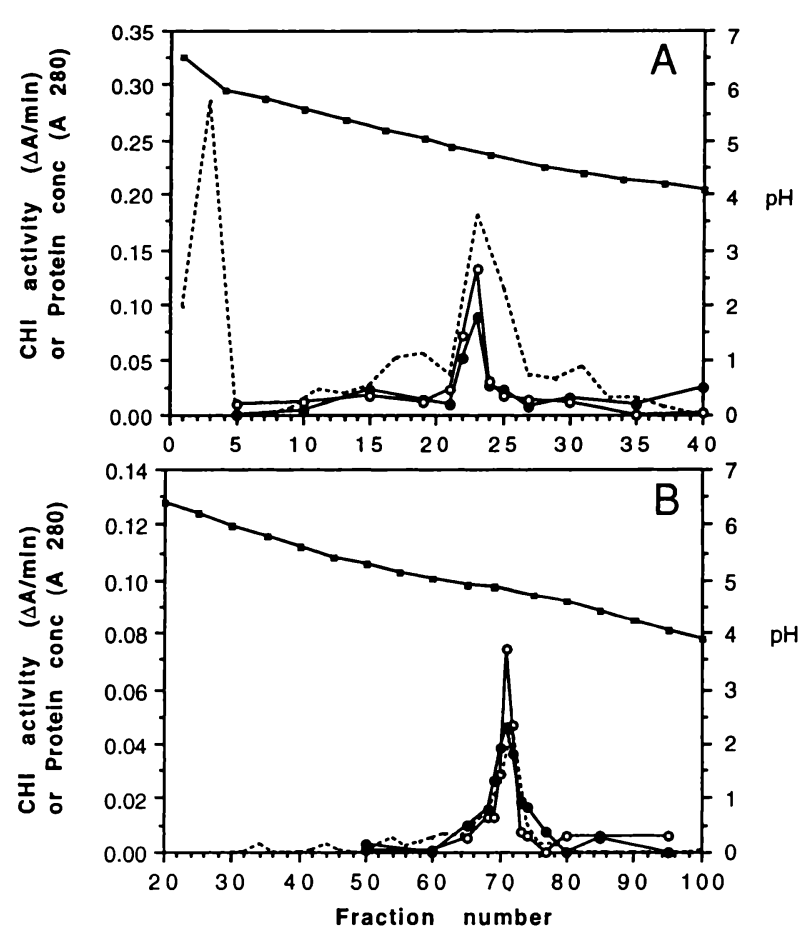

FIG. 5. Chromatofocusing analysis of $\mathrm{CHI}$ from stems of $C$. senilis. The peak of $\mathrm{CHI}$ activity collected from the first column run (A, 5.5$\mathrm{ml}$ fractions) was rechromatographed (B, 1-ml fractions). Enzyme activities were measured with $2^{\prime}, 4,4^{\prime}, 6^{\prime}$-tetrahydroxychalcone $(\bullet)$ or $2^{\prime}, 4^{\prime}, 6^{\prime}$-trihydroxychalcone $(O)$ as substrates. Activity represents the activity of $25 \mu \mathrm{l}$ of each fraction. The columns were eluted with polybuffer to give a $\mathrm{pH}$ gradient ( $\square$ ) from 7 to 4 . Protein concentration (-.--) was determined by measuring $A_{280}$. 
TABLE II

Substrate Specificity of the (Hydroxy)-cinnamate: CoA Ligase from Cell Suspension Cultures of $C$. senilis

\begin{tabular}{|c|c|c|c|c|c|}
\hline \multirow[b]{2}{*}{ Substrate } & \multicolumn{3}{|c|}{ Specific activity ( $\mu \mathrm{kat} / \mathrm{g})$} & \multirow[b]{2}{*}{$\begin{array}{c}\lambda \mathrm{nm} \text { for } \mathrm{CoA} \\
\text { esters }\end{array}$} & \multirow[b]{2}{*}{$\epsilon\left(\mathrm{cm}^{2} / \mathrm{mol}\right)$} \\
\hline & Elicited & Nonelicited & $\begin{array}{c}\text { Relative } \\
\text { activity (\%) }\end{array}$ & & \\
\hline 4-Coumaric acid & 0.226 & 0.034 & 74 & $333^{a}$ & $23 \times 10^{6}$ \\
\hline Cinnamic acid & 0.223 & 0.018 & 73 & $311^{a}$ & $22 \times 10^{6}$ \\
\hline Caffeic acid & 0.306 & 0.061 & 100 & $363^{a}$ & $13 \times 10^{6}$ \\
\hline Ferulic acid & 0.272 & 0.017 & 89 & $345^{a}$ & $19 \times 10^{6}$ \\
\hline Sinapic acid & 0.000 & 0.007 & 0 & $352^{b}$ & $20 \times 10^{6}$ \\
\hline 4-Methoxy-cinnamic acid & 0.216 & 0.007 & 71 & $339^{a}$ & $27 \times 10^{6}$ \\
\hline
\end{tabular}

Note. Data are the average of duplicate measurements by a spectrophotometric assay at the long-wave absorption maxima of the corresponding CoA thiol esters. Reported long-wave absorption maxima and molar extinction coefficients $(\epsilon)$ for CoA esters of cinnamic acid derivatives are summarized.

${ }^{a}$ Gross and Zenk (19).

${ }^{b}$ Lüderitz et al. (20).

in unchallenged intact plants of $C$. senilis, the more usual B-ring hydroxylated flavonoids accumulate (11). The purpose of the present study was to describe the enzymatic activities present in elicited cell cultures in relation to the accumulation of B-ring deoxy flavonoids. As elicited cultures only produce trace amounts of one B-ring hydroxy flavonoid (10), an efficient mechanism
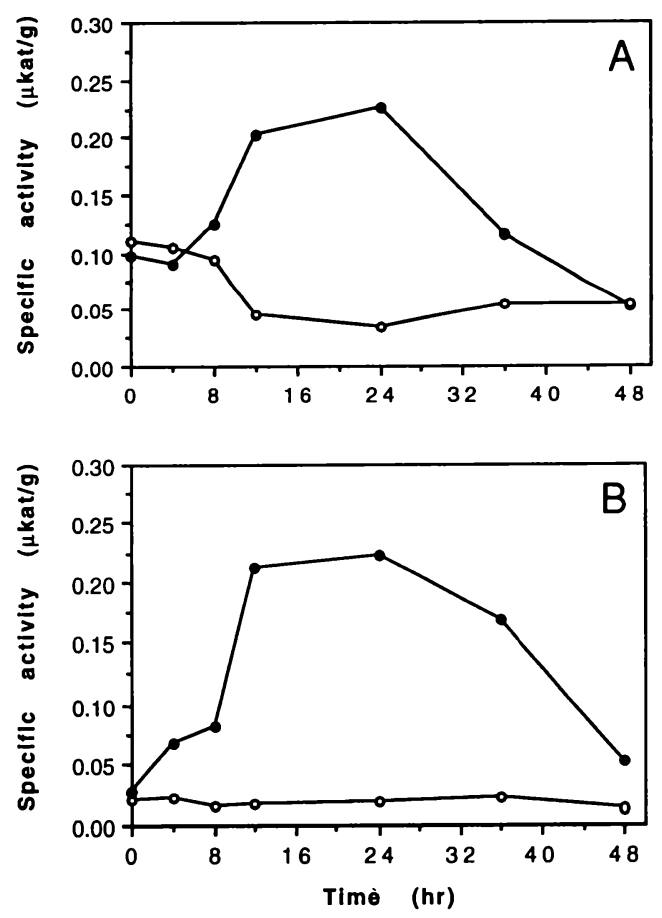

FIG. 6. Induction of (hydroxy)-cinnamate:CoA ligase activity in elicited $(\bullet)$ and $\mathrm{H}_{2} \mathrm{O}$-treated $(\mathrm{O})$ cultures of $C$. senilis. Specific activities ( $\mu \mathrm{kat} / \mathrm{g}$ protein) were determined with 4-coumaric acid (A) and cinnamic acid (B) as substrates. must be present to produce cinnamoyl CoA as substrate for chalcone synthase leading to $2^{\prime}, 4^{\prime}, 6^{\prime}$-trihydroxychalcone, the first C15 precursor of the B-ring deoxy compounds (Fig. 2).

Activity of $C$. senilis CHI was observed with $2^{\prime}, 4,4^{\prime}, 6^{\prime}$-tetrahydroxychalcone and $2^{\prime}, 4^{\prime}, 6^{\prime}$-trihydroxychalcone, but not $2^{\prime}, 4,4^{\prime}$-trihydroxychalcone, reflecting the substitution patterns of the known flavonoids of $C$. senilis; all possess 5- and 7-hydroxyl groups which arise as the $4^{\prime}$ - and $6^{\prime}$-hydroxyl groups of the corresponding chalcones and are either unsubstituted on the B-ring (and therefore derived from $2^{\prime}, 4^{\prime}, 6^{\prime}$-trihydroxychalcone) or hydroxylated at the $4^{\prime}$ position (derived from $2^{\prime}, 4,4^{\prime}, 6^{\prime}$-tetrahydroxychalcone). Activity with $2^{\prime}, 4,4^{\prime}$-trihydroxychalcone is observed with legume CHIs, which accumulate 5-deoxy flavonoid derivatives as phytoalexins (18). As parsley and petunia

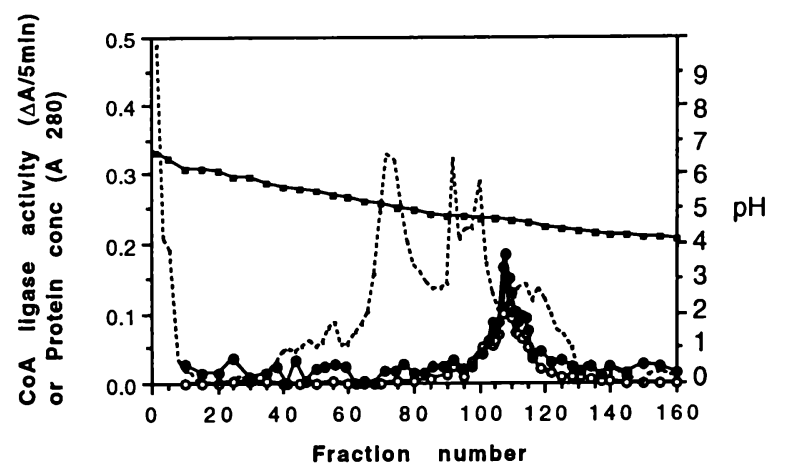

FIG. 7. Chromatofocusing analysis of (hydroxy)-cinnamate:CoA ligase from elicited cell cultures of $C$. senilis. Enzyme activities were measured with 4-coumaric acid $(\bullet)$ or cinnamic acid $(O)$ as substrates. The column was eluted with polybuffer to give a $\mathrm{pH}$ gradient (匹) from 7 to 4 . Protein concentration (--.--) was determined by measuring $A_{280}$. 


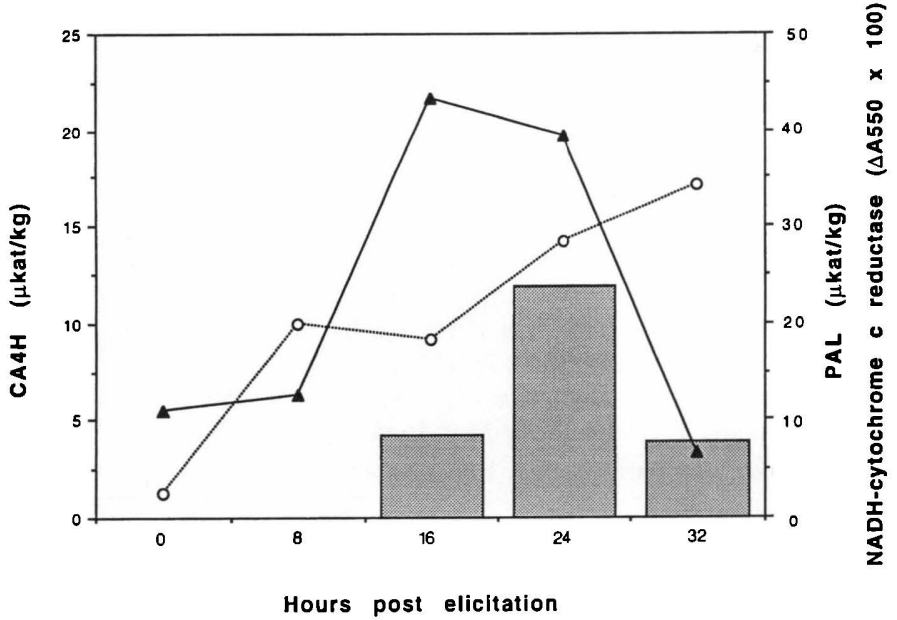

FIG. 8. Activities of PAL ( $\mathbf{\Delta}$ ), CA4H (bars), and NADH-dependent cytochrome C-reductase $(O)$ in elicitor-treated cell cultures of $C$. senilis. $\mathrm{CA} 4 \mathrm{H}$ and cytochrome $\mathrm{C}$ reductase were measured in microsomal preparations. No $\mathrm{CA} 4 \mathrm{H}$ activity was observed in unelicited cultures.

CHIs were active against both $2^{\prime}, 4,4^{\prime}, 6^{\prime}$-tetrahydroxyand $2^{\prime}, 4^{\prime}, 6^{\prime}$-trihydroxychalcones but neither plant has been reported to accumulate B-ring deoxy flavonoids, it would appear that a $4^{\prime}$-hydroxy group is not required for the action of chalcone isomerase.

Although two isoforms of CHI were identified in the cactus cultures, both were active against $2^{\prime}, 4,4^{\prime}, 6^{\prime}$-tetrahydroxychalcone and $2^{\prime}, 4^{\prime}, 6^{\prime}$-trihydroxychalcone, and both were induced by chitin treatment. Isoforms of CHI have been previously purified from mung bean (Phaseolus aureus) and garbanzo bean seedlings (Cicer arietinum), and have also been detected in parsley ( $\mathrm{Pe}$ troselinum hortense) (21). Although isoform I of C. senilis CHI has a somewhat higher affinity for $2^{\prime}, 4^{\prime}, 6^{\prime}$ trihydroxychalcone than isoform II, and isoform II has a somewhat greater affinity for $2^{\prime}, 4,4^{\prime}, 6^{\prime}$-tetrahydroxychalcone than isoform $I$, our data indicate that accumulation of B-ring deoxy flavonoids in the elicited cactus cultures is unlikely to be associated with the specific induction of a novel form of CHI.

If the unsubstituted aromatic ring of cinnamic acid is to be incorporated into the B-rings of the elicitorinduced flavonoids, the (hydroxy)-cinnamate:CoA ligase in cactus cultures must be able to activate cinnamic acid to cinnamoyl-CoA. Crude extracts from the cactus cultures were indeed active with cinnamic acid, as well as 4-coumaric, ferulic, caffeic, and 4-methoxycinnamic acids, but not, however, sinapic acid. Lack of activity against sinapic acid suggests that the lignin of the mature cactus might lack syringyl units, and thus be similar to that of softwood gymnosperms. In most plants, the CoA ligase which activates 4-coumaric acid exhibits little or no activity against cinnamic acid (22-
25), although enzymatic activation of cinnamic acid to the CoA thiol ester has been reported in crude enzyme extracts from sugar beet (26), and a partially purified soybean coumarate:CoA ligase has been shown to exhibit approximately $10 \%$ of the activity against cinnamic acid as observed with 4-coumaric acid (27).

Activities of the CoA ligase versus cinnamic and 4coumaric acids were coinduced and were not separable by chromatofocusing, suggesting that the cactus cultures may have a single (hydroxy) cinnamate:CoA ligase with multiple substrate specificity. Although the resolution of this analysis prevents us from completely ruling out the possibility of a cinnamate-specific CoA ligase isoform, these data nevertheless strongly suggest that the B-ring hydroxylation pattern of the elicitor-induced flavonoids is not regulated at the level of CoA ligase, although the presence of a CoA ligase with an unusually high activity against cinnamic acid is clearly of central importance for the synthesis of B-ring deoxy flavonoids. Substrate availability (i.e., cinnamate vs coumarate) for the CoA ligase would therefore appear to be the factor responsible for the accumulation of flavonoids with unsubstituted B-rings in the elicited cactus cultures, as the cultures contain all the enzymatic activities necessary for formation of both B-ring deoxy- and hydroxy-intermediates. Essentially, this could be controlled by two distinct mechanisms: (i) lack of induction of $\mathrm{CA} 4 \mathrm{H}$ and therefore high cinnamate to coumarate ratios leading to preferential activation of cinnamate by CoA ligase, (ii) metabolic compartmentation of the PAL and CoA ligase reactions such that $\mathrm{CA} 4 \mathrm{H}$ is bypassed in the elicited cultures. A third alternative could be the existence of novel enzymatic processes for the deoxygenation of coumarate or some later intermediate in the pathway, but this seems extremely unlikely, particularly in view of the strong activity of the CoA ligase for cinnamate.

$\mathrm{CA} 4 \mathrm{H}$ activity was strongly induced by elicitor treatment, the specific activity being approximately half that found in fungally infected wheat leaves which accumulate lignin via the PAL and $\mathrm{CA} 4 \mathrm{H}$ reactions (25) and approximately equal to that reported in elicited alfalfa cell cultures, which accumulate B-ring hydroxy flavonoid derivatives (28). Furthermore, the ratio of induced PAL to $\mathrm{CA} 4 \mathrm{H}$ activities was lower in the cactus than in the alfalfa cultures. Thus, it is very unlikely that lack of utilization of coumarate for flavonoid synthesis results from lack of enzymatic capacity for hydroxylation of cinnamate. We are therefore left with the possibility that, although $\mathrm{CA} 4 \mathrm{H}$ is induced as normally observed in cell cultures producing phenylpropanoidderived phytoalexins (29), its activity is somehow bypassed. This would imply metabolic compartmentation, at least at the level of the PAL, CA4H, and CoA ligase reactions. Chaneling of phenylalanine through the PAL and $\mathrm{CA} 4 \mathrm{H}$ reactions has been previously reported (30). 
Our data suggest either a disruption of this process in elicited cells or an establishment of a new direct channel between the elicited PAL and CoA ligase enzymes, leading directly to the formation of cinnamoyl $\mathrm{CoA}$. Further compartmentation of the subsequent reactions may occur, but this would not appear to be essential.

Although we now understand many details of the transcriptional regulation of phenylpropanoid/flavonoid biosynthesis $(5,29)$, our understanding of how the pathways are organized in the cell is virtually nonexistent. Evidence for metabolic compartmentation in phenylpropanoid synthesis has come primarily from precursor feeding experiments and attempts to immunolocalize enzymes such as PAL and CHS (30). Elicited $C$. senilis cultures may be a good model system for future studies on metabolic compartmentation, as they appear to feature a mechanism for avoiding a key reaction of phenylpropanoid synthesis. The recent availability of techniques for determining physical interactions between proteins in vivo (31) should now make it possible to analyze directly the molecular basis of metabolic compartmentation in plant secondary product biosynthesis.

\section{REFERENCES}

1. Hain, R., Reif, H.-J., Krause, E., Langebartels, R., Kindl, H., Vornam, B., Wiese, W., Schmelzer, E., Schreier, P. H., Stöcker, R. H., and Stenzel, K. (1993) Nature 361, 153-156.

2. Dixon, R. A. (1986) Biol. Rev. 61, 239-291.

3. Lawton, M. A., and Lamb, C. J. (1987) Mol. Cell. Biol. 7, 335341.

4. Lamb, C. J., Lawton, M. A., Dron, M., and Dixon, R. A. (1989) Cell 56, 215-224.

5. Dixon, R. A., Choudhary, A. D., Dalkin, K., Edwards, R., Fahrendorf, T., Gowri, G., Harrison, M. J., Lamb, C. J., Loake, G. J., Maxwell, C. A., Orr, J., and Paiva, N. L. (1992) in Phenolic Metabolism in Plants (Stafford, H. A., and Ibrahim, R. K., Eds.), pp. 91-138, Plenum, New York.

6. Paré, P. W., Mischke, C. F., Edwards, R., Dixon, R. A., Norman, H. A., and Mabry, T. J. (1992) Phytochemistry 31, 149-153.

7. Bonness, M. S., Paré, P. W., and Mabry, T. J. (1993) Cactus Succulent J. 65, 144-147.
8. Paré, P. W., Dmitrieva, N., and Mabry, T. J. (1991) Phytochemistry 30, 1133-1135.

9. Liu, Q., Markham, K. R., Paré, P. W., Dixon, R. A., and Mabry, T. J. (1993) Phytochemistry 32, 925-928.

10. Liu, Q., Dixon, R. A., and Mabry, T. J. (1993) Phytochemistry 34, 167-170.

11. Liu, Q., Liu, M., Mabry, T. J., and Dixon, R. A. (1994) Phytochemistry 36, 229-231.

12. Heller, W., and Forkmann, G. (1988) in The Flavonoids: Advances in Research Since 1980 (Harborne, J. B., Ed.), pp. 399425, Chapman and Hall, New York.

13. Fliegmann, J., Schröder, G., Schanz, S., Britsch, L., and Schröder, J. (1992) Plant Mol. Biol. 18, 489-503.

14. Moustafa, E., and Wong, E. (1967) Phytochemistry 6, 625-632.

15. Edwards, R., and Kessmann, H. (1992) in Molecular Plant Pathology: A Practical Approach (Gurr, S. J., McPherson, M. J., and Bowles, D. J., Eds.), pp. 45-62, IRL Press, Oxford.

16. Knobloch, K.-H., and Hahlbrock, K. (1975) Eur. J. Biochem. 52, $331-320$.

17. Wray, J. L., and Filner, P. (1970) Biochem. J. 119, 715-725.

18. Dixon, R. A., Blyden, E. R., Robbins, M. P., Van Tunen, A. J., and Mol, J. N. M. (1988) Phytochemistry 27, 2801-2808.

19. Gross, G. G., and Zenk, M. H. (1966) Z. Naturforsch. 21b, 683690.

20. Lüderitz, T., Schatz, G., and Grisebach, H. (1982) Eur. J. Biochem. 123, 583-586.

21. Hahlbrock, K., Wong, E., Schill, L., and Grisebach, H. (1970) Phytochemistry 9, 949-958.

22. Kutsuki, H., Shimada, M., and Higuchi, T. (1982) Phytochemistry 21, 267-271.

23. Grand, C., Boudet, A., and Boudet, A. M. (1983) Planta 158, 225-229.

24. Heinzmann, U., Seitz, U., and Seitz, U. (1977) Planta 135, 313318.

25. Maule, A. J., and Ride, J. P. (1983) Phytochemistry 22, 11131116.

26. Walton, E., and Butt, V. S. (1971) Phytochemistry 10, 295-304.

27. Lindl, T., Kreuzaler, F., and Hahlbrock, K. (1973) Biochim. Biophys. Acta 302, 457-464.

28. Kessmann, H., Choudhary, A. D., and Dixon, R. A. (1990) Plant Cell Rep. 9, 38-41.

29. Dixon, R. A., and Harrison, M. J. (1990) Adv. Genet. 28, 165234.

30. Hrazdina, G., and Jensen, R. A. (1992) Annu. Rev. Plant Physiol. Plant Mol. Biol. 43, 241-267.

31. Chien, C.-T., Bartel, P. L., Sternglanz, R., and Fields, S. (1991) Proc. Natl. Acad. Sci. USA 88, 9578-9582. 